\title{
Melanoma of the Conjunctiva cT1c TNM
} Finding v7

National Cancer Institute

\section{Source}

National Cancer Institute. Melanoma of the Conjunctiva CT1C TNM Finding v7. NCI

Thesaurus. Code C88645.

Melanoma of the bulbar conjunctiva more than 2 but less than or equal to 3 quadrants.

(from AJCC 7th Ed.) 